\title{
INVESTASI DANA HAJI UNTUK PEMBANGUNAN INFRASTRUKTUR DI INDONESIA DALAM PANDANGAN ISLAM
}

\author{
M. Fajri Syahroni Siregar \\ Universitas Islam Negeri Sumatera Utara \\ E-mail: syahronisiregar1404@gmail.com
}

\begin{tabular}{|c|c|c|}
\hline Received & Revised & Accepted \\
\hline 10 Januari 2021 & 10 Februari 2021 & 28 Maret 2021 \\
\hline
\end{tabular}

\section{HAJI FUND INVESTATION TO CONSTRUCT THE INFRASTRUCTURE IN INDONESIA BASED ON ISLAM}

\begin{abstract}
This study aims to determine how the provisions of the benefits planned by the government to build infrastructure in Indonesia in the analysis of the benefits and mafsadat of Islamic Law. To find out the answer to this question, a qualitative research was carried out with the type of research, namely literature study and as the data obtained were taken through several valid news and also several literature books, both in Arabic and in Indonesian. The results of this study indicate that the actual benefit of not using Hajj funds is greater than if they were used. Apart from that, the existing mafsadat from infrastructure development is even greater considering that of the many investments made, not many get a profit. Therefore, the law obtained from this study shows that it is not permissible to invest hajj funds for infrastructure development.

Keywords: investation, haj fund, infrastructure, and jurisprudence.
\end{abstract}

\begin{abstract}
Abstrak
Penelitian ini bertujuan untuk mengetahui bagaimana ketentuan maslahat yang direncanakan pemerintah untuk membangun infrastruktur di Indonesia dalam analisis maslahat dan mafsadat Hukum Islam. untuk mengetahui jawaban dari pertanyaan ini maka dilakukanlah penelitian kualitatif dengan jenis penelitian yaitu Studi pustaka dan sebagai data yang diperoleh diambil melalui beberapa berita yang falid dan juga beberapa literature buku, baik yang berbahasa Arab ataupun berbahasa Indonesia. Hasil penelitian ini menunjukkan bahwa sebenarnya kemaslahatan untuk tidak menggunakan dana ibadah haji lebih besar daripada apabila dipergunakan. Selain daripada itu, kemafsadatan yang ada dari pembangunan Infrastruktur lebih besar kemafsadatannya mengingat dari sekian banyak investasi yang dilakukan tidak banyak yang mendapatkan keuntungan. Maka dari itu hukum
\end{abstract}




\section{Fajri Syahroni Siregar}

Investasi Dana Haji untuk Pembangunan......

yang didapat dari penelitian ini menunjukkan tidak diperbolehkannya menginvestasikan dana haji untuk pembangunan infrastruktur.

Kata kunci: investasi, dana haji, infrastruktur, dan hukum Islam

\section{Pendahuluan}

Pembangunan infrastruktur di negara indonesia tak kunjung usai, dari semnjak dahulu hingga sekarang pemerintah indonesia tidak pernah berhenti membahas dan merencanaan pembangunan infrastruktur yang ada di negara kita ini. Segala proyek yang direncanakan tak pernah henti, setelah selesai satu proyek datang lagi proyek yang lain, setelah selesai akan direncanakan proyek lainnya lagi, segala sumber dana dipersiapkan untuk merealisasikan program pemerintah ${ }^{1}$.

Belakangan ini sempat menjadi berita hangat di negara indonesia, yaitu berita tentang pemerintah yang ingin membangun infrastruktur di negara tercinta ini dengan menggunakan dana yang asalnya dipergunakan untuk menunaikan ibadah haji. Berita ini sempat menjadi berita yang hangat dibincangkan di media sosial. Menjadi wacana bagi masyarakat indonesia. Bagaimana tidak sedangkan pembangunan di setiap negara merupakan hal yang sangat substansial dalam mewujudkan suatu negara sebagai negara yang maju².

Investasi yang merupakan cara untuk membangun infrastruktur di suatu negara merupakan cara yang benar dan pantas dilakukan demi tercapainya pembangunan di suatu negara. Sistem investasi yang direncanakan presiden indonesia tentunya menimbulkan beberapa manfaat di berbagai sisi, selain untuk pembangunan, dana yang digunakan juga akan berkesinambungan manfaatnya untuk semua kalangan, baik bagi calon haji ataupun bukan calon haji, bahkan bagi orang yang bukan beragama islam. Maka jelaslah bahwa investasi yang direncanakan pemerintah indonesia berotensi besar untuk menciptakan kemaslahatan bagi semua penduduknya ${ }^{3}$.

Namun, di lain dari itu, ada yang sangat penting untuk diperhatikan dan dipertimbangkan, bahkan dikaji dalam investasi untuk pembangunan ini. Terutama bagi mereka yang beragama islam. Tentunya semua umat islam sangat prihatin dengan keadaan ini. Semua itu dillatarbelakangi karena agama islam telah mengatur semua kemaslahatan dengan cara yang baik dan benar. Islam sudah mengonsepkan semua kemaslahatan dan semua tata cara dalam bertasharruf dan bermuamalah ${ }^{4}$.

Hal yang sangat penting diperhatikan dalam proses investasi ini adalah cara yang dilakukan pemerintah indonesia ini merupakan cara yang baru, dan cara yang

\footnotetext{
${ }^{1}$ Adi Wibowo, "Tinjauan Hukum Islam Terhadap Praktik Pinjammeminjam Uang Di Desa Nglorog Kec. Sragen Kab. Sragen," Skripsi--UIN Sunan Kalijaga, Yogyakarta (2013).

${ }^{2}$ Hasan Baharun et al., "MODERNISASI PENDIDIKAN DI PONDOK PESANTREN: Studi Tentang Pemanfaatan Sistem Aplikasi Pedatren Dalam Meningkatkan Mutu Layanan Pondok Pesantren," Al-Tarbawi Al-Haditsah: Jurnal Pendidikan Islam 6, no. 1 (2021): 1-22.

${ }^{3}$ Ali Miftakhu Rosyad, "The IMPLEMENTASI NILAI-NILAI MULTIKULTURALISME MELALUI PEMBELAJARAN PENDIDIKAN AGAMA ISLAM (THE IMPLEMENTATION OF MULTICULTURALISM VALUES THROUGH LEARNING OF ISLAMIC RELIGION EDUCATION)," Risâlah, Jurnal Pendidikan dan Studi Islam 5, no. 1 (2019): 1-18.

${ }^{4}$ Hasan Baharun, "Management Information Systems in Education: The Significance of e-Public Relation for Enhancing Competitiveness of Higher Education," in Journal of Physics: Conference Series, vol. 1175 (IOP Publishing, 2019), 12151.
} 


\section{Fajri Syahroni Siregar}

Investasi Dana Haji untuk Pembangunan......

dilakukan presiden ini adalah mengolah uang masyarakat yang ditujukan untuk ibadah. Tentukan akan timbul beberapa pertanyaan yang dapat menyinggung dan membahas masalah ini. Karena walaupun investasi ini menghasilkan kemaslahatan, namun di sisi lain investasi yang akan dilakukan itu dapat berpotensi menimbulkan kemudharatan bagi calon haji yang ingin menunaikan ibadah haji. Dan potensi ini sering menjadi sorotan karena besar kemungkinan yang ditimbulkan dari efek sampingnya akan berdampak penting terhadap para calon jama'ah haji ${ }^{5}$.

Menurut tinjauan kajian islam. Sebaiknya suatu dana dialokasikan sesuai dengan fungsinya, memang dari berbagai literatur yang ada, telah banyak ulama klasik yang membahas kaidah yang berkaitan dengan pengolahan dana rakyat yang dilakukan pemerintah. Namun pengolahan dana yang direncanakan pemerintah indonesia ini sedikit lebih membutuhkan terhadap kajian yang lebih mendalam bagi para intelektual muslim $^{6}$, semua itu karena investasi yang direncanakan ini mengandung beberapa perbedaan yang menyalahi kaidah fiqih dan kaidah ushul fiqih yang telah kita ketahui.

Dari penjelasan yang kami tuliskan dalam tulisan ini, kami berharap agar kiranya hasil yang dihasilkan dari makalah kami ini dapat memberi manfaat bagi khazanah keilmuan dan kajian fiqih. Dan memberikan pemahaman yang memuaskan bagi kebutuhan intelektual kita.

\section{Metode Penelitian}

Penelitian ini menggunakan pendekatan kualitatif dengan jenis studi pustaka (library reseach), karena penelitian ini akan berusaha menganalisis secara kritis yang berkaitan dengan pengelolaan investasi dana haji dalam pengelolaan infrastruktur di Indonesia menurut pandangan hukum Islam. Data penelitian ini diperoleh dari berbagai macam berita dan dokumentasi yang berkaitan dengan kebijakan pemerintah terkait pengelolaan dana haji dari media cetak dan elektronik. Lalu data tersebut akan dianalisis secara tri angulasi.

\section{Hasil dan Pembahasan Definisi Investasi}

Pengertian investasi menurut Haming dan Basalamah investasi ialah pengeluaran pada saat sekarang untuk membeli aktiva real (tanah, rumah, mobil, dan lain-lain) atau juga aktiva keuangan mempunyai tujuan untuk mendapatkan penghasilan yang lebih besar lagi dimasa yang mendatang, selanjutnya dikatakan juga investasi ialah aktivitas yang berkaitan dengan usaha penarikan sumber-sumber (dana) yang digunakan untuk mengadakan barang modal pada saat sekarang, dan dengan barang modal tersebut akan dihasilkan aliran produk baru di masa yang akan datang?

\footnotetext{
5 Darwis Sadir, “Piagam Madinah (Al-Qanun)," Jurnal Pemikiran dan Pembaharuan Hukum Islam 5, no. 1 (2013): 250-257.

${ }^{6}$ Ali Miftakhu Rosyad, “Urgensi Inovasi Pembelajaran Islam Dalam PAI," al-Afkar, Journal for Islamic Studies 2, no. 1 (2019): 64-86.

${ }^{7}$ Hasan Baharun, Adi Wibowo, and Siti Nur Hasanah, "Kepemimpinan Perempuan Dalam Menciptakan Sekolah Ramah Anak," Quality 9, no. 1 (2021): 87-102.
} 


\section{Fajri Syahroni Siregar}

Investasi Dana Haji untuk Pembangunan......

Pengertian investasi menurut Mulyadi Investasi ialah pengaitan sumbersumber dalam jangka panjang untuk mendapatkan hasil laba di masa yang akan datang. Selain itu, Pengertian investasi menurut Sadono Sukirno Investasi diartikan ialah sebagai pengeluaran atau pembelanjaan penanam-penanam suatu modal atau perusahaan untuk membeli barang-barang modal dan juga perlengkapan-perlengkapan produksi untuk menambah kemampuan memproduksi barang-barang dan juga jasa-jasa yang tersedia dalam perekonomian. Pengertian Investasi menurut James $\mathrm{C}$ Van Horn kegiatan yang dilangsungkan ialah dengan memanfaatkan kas pada sekarang ini, dengan tujuan untuk mendapatkan hasil barang di masa yang akan datang.

\section{Definisi infrastruktur dan Transportasi}

Infrastruktur adalah berbagai macam fasilitas fisik yang diperlukan dan dikembangkan oleh beberapa agen publik yang memiliki tujuan untuk bisa memenuhi tujuan ekonomi dan sosial serta fungsi pemerintahan dalam hal tenaga listrik, penyediaan air, transportasi, pembuangan limbah dan pelayanan-pelayanan lainnya yang sama ${ }^{9}$.

Terdapat banyak pengertian infrastruktur menurut para ahli. Kalau kita mengambil benang merahnya maka bisa dikatakan bahwa infrastruktur adalah semua fasilitas baik non fisik maupun fisik yang sengaja dibangun oleh pereorangan atau pemerintah untuk menyupport terlaksananya kegiatan masyarakat. Pembangunan infrastruktur termasuk sesuatu yang penting pengadaannya dimana harus disegerakan karena berkaitan dengan kebutuhan dasar masyarakat setiap hari dalam lingkungan sosial dan ekonomi.

Infrastruktur publik termasuk tanggung jawab pemerintah yang menjadi tanggung jawab dan kompensasi dari pembayaran pajak oleh warga negara. Infrastruktur publik tergolong sangat penting artinya karena sangat dapat mempengaruhi kelancaran kegiatan sosial dan ekonomi masyarakat. Contohnya infrastruktur transportasi.

Sedangkan, Infrastruktur Transportasi adalah infrastruktur yang menyupport sekaligus bermanfaat untuk kelangsungan para pengguna alat transportasi. Infrastruktur transportasi yang baik seharusnya dapat memberikan kenyamanan sekaligus kenyamanan untuk para penumpang. Contoh infrastruktur transportasi yaitu pelabuhan, jalan tol, jalan-jalan raya, bandara, rambu lalu lintas, stasiun dan sebagainya.

Contohnya jalan raya, dengan adanya pembangunan jalan raya yang lengkap dan baik maka tentu saja sangat berarti untuk kelancaran transportasi sehingga hasil pertanian pun dapat didistribusikan, para karyawan dapat ke kantor secara mudah, distribusi barang pun dapat mencapai pelosok daerah, anak-anak bisa bersekolah dengan mudah, dan masih banyak lagi manfaatnya yang bisa kita rasakan. Bisa kita bayangkan kalau jalan raya hancur atau rusak, begitu banyak kegiatan masyarakat menjadi terhambat. Pendek kata, bahwa infrastruktur jalan raya berarti jalan raya

\footnotetext{
${ }^{8}$ Ikatan Akuntan Indonesia. 2009. Pernyataan Standar Akuntansi Keuangan 16. Jakarta: Salemba Empat.

${ }^{9}$ KENT D. PETTERSON TERRENCE E. DEAL., “SHAPING SCHOOL CULTURE” (n.d.).
} 


\section{Fajri Syahroni Siregar}

Investasi Dana Haji untuk Pembangunan......

tersebut dibuat semata-mata untuk dipakai oleh masyarakat luas. Tidak hanya orang-orang tertentu.

Ada juga infrastruktur yang dibangun oleh kelompok atau perorangan tertentu. Contohnya perusahaan pertambangan yang membangun fasilitas untuk dapat menunjang kelancaran kegiatan perusahaan seperti sistem kelistrikan, jraingan komputer, gedung dan masih banyak lagi yang lainnya. Apalagi untuk perusahaan-perusahan besar yang mempunyai kawasan yang cukup luas, biasanya mereka membangun jalan raya, swalayan, penginapan karyawan dan lain-lain ${ }^{10}$.

Ada tiga jenis infrastruktur yakni infrastruktur lunak, infrastruktur keras non fisik dan infrastruktur keras. Kita sudah mengetahui secara baik mengenai apa itu infrastruktur keras yakni infrastruktur yang mempunyai bentuk fisik dan paling banyak berkaitan dengan kepentingan masyarakat. Adapun contohnya jalan raya, dermaga, bandara dan lain-lain. Infrastruktur keras non fisik sesuai penamaannya tak mempunyai bentuk fisik yang nyata akan tetapi ikut mendukung infrastruktur keras yang lainnya. Contohnya, jaringan komunikasi seperti internet dan telepon, ketersediaan air bersih, pasokan lisrik, pasokan energi dan lain-lain.

Kita tak bisa melihat pasokan listrik secara nyata, akan tetapi kita sangat memerlukan pasokan listrik yang disalurkan lewat kabel listrik yang dipasang pada seluruh kota. Sementara itu, infrastruktur lunak mencakup lembaga-lembaga pemerintahan dan kerangka institusional. Selain memerlukan jembatan dan jalan raya, kita sebagai masyarakat pasti memerlukan sistem yang mengelola pemerintahan dan kepentingan umum seperti kepolisian untuk ketertiban masyarakat, kantor camat, lurah untuk urusan kemasyarakatan, pelayanan kantor pos dan masih banyak lagi yang lainnya.

\section{Pengertian Infrastruktur Jaringan dan teknologi informasi}

Infrastruktur jaringan adalah kelompok-kelompok yang saling berkaitan dari sistem komputer terintegrasi dan terkoneksi dengan berbagai macam bagian dari arsitektur telekomunikasi. Infrastruktur teknologi informasi adalah kumpulan komponen teknologi yang terdiri dari hardware, sumber daya manusia, database, software, telekommunikasi dan prosedur ${ }^{11}$. Sedangkan infrastruktur teknologi informasi menurut laudon terdiri atas software, storage, hardware dan jaringan.

Sistem infrastruktur didefinisikan sebagai struktur dasar atau fasilitas, peralatan, instalasi yang dibangun dan yang diperlukan untuk berfungsinya sistem ekonomi masyarakat dan sistem sosial (Grigg, 2000 dalam Kodoatie, R.J. 2005). Sistem infrastruktur termasuk pendukung utama dari sistem ekonomi dan sistem sosial dalam kehidupan masyarakat.

Disini, infrastruktur memiliki peran penting sebagai mediator sistem sosial dan ekonomi dalam tatanan kehidupan lingkungan dan manusia. Kondisi tersebut agar harmonisasi kehidupan bisa tetap terjaga dalam arti infrastruktur tak

\footnotetext{
${ }^{10}$ Ali Miftakhu Rosyad and Muhammad Anas Maarif, "PARADIGMA PENDIDIKAN DEMOKRASI DAN PENDIDIKAN ISLAM DALAM MENGHADAPI TANTANGAN GLOBALISASI DI INDONESIA," Nazhruna: Jurnal Pendidikan Islam 3, no. 1 (2020): 75-99.

${ }^{11}$ Tedi Priyatna, “Inovasi Pembelajaran PAI Di Sekolah Pada Era Disruptive Innovation," Jurnal Tatsqif 16, no. 1 (2018): 40.
} 


\section{Fajri Syahroni Siregar}

Investasi Dana Haji untuk Pembangunan......

kekurangan (berpengaruh pada manusia), akan tetapi juga tak berlebihan tanpa memperhitungkan daya dukung lingkungan alam karena dapat merusak alam dan pada akhirnya berpengaruh juga kepada manusia dan makhluh hidupnya.

Dalam hal ini, lingkungan alam merupakan pendukung sistem infrastruktur dan sistem ekonomi disupport oleh sistem infrastruktur, sistem sosial sebagai objek dan sasaran didukung oleh adanya sistem ekonomi. Analoginya seperti dibawah ini: Pengelompokan sistem infrastruktur bisa dibedakan menjadi (Grigg, 2000 dalam Kodoatie, R.J, 2005):

1. Grup bangunan

2. Grup distribusi dan produksi energy

3. Grup transportasi (jalan, rel)

4. Grup komunikasi

5. Grup Keairan

6. Grup pengelolaan limbah

7. Grup pelayanan transportasi (terminal, bandara, pelabuhan, stasiun dan lainlain) $)^{12}$.

\section{Sistem Pengolahan Uang Rakyat untuk Kemaslahatan Bersama}

Seorang pemimpin boleh mengolah uang rakyat demi tujuan untuk membangun dan memberikan kebaikan dan kemaslahatan terhadap penduduk di suatu tempat yang ia pimpin. Namun di lain dari pada itu, ada beberapa hal yang harus kita perdalami dalam pembahasan kebijakan imam ini ${ }^{13}$.

1. Tinjauan terhadap Kaidah yang sangat masyhur, yang berbunyi :

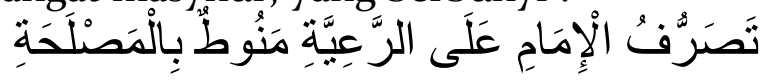

Kebijakan seorang pemimpin terhadap rakyatnya haruslah bergantung terhadap kemaslahatan ${ }^{14}$.

Dari kaidah di atas ini, kita dapat mengambil suatu kesimpulan bahwa bolehlah seorang imam mengambil kebijakan terhadap harta rakyatnya. Dan kaidah ini mengisyaratkan kita terhadap kebijakan pemimpin terhadap harta rakyatnya. Maka dari itu bolehlah seorang pemimpin mengambil kebijakan terhadap uang rakyatnya.

Setelah mengkaji kaidah di atas, mungkin ada beberapa pertanyaan yang menyantol di fikiran kita, yaitu, jika kaidah di atas adalah kebijakan yang dilakukan pemimpin, lalu bagaimana jika yang mengambil kebijakan adalah bukan pemimpin?. Karena tentu saja ada beberapa oknum yang ikut membantu, seperti tukang bangunan yang nantinya akan membangun jalan tol.

Untuk menjawab dari pertanyaan ini, maka ada baiknya kita melihat kepada kaidah yang dihidangkan syaikh iz bin abdis salam dalam kitabnya al mantsur yang berbunyi:

\footnotetext{
12 https://informasiana.com/pengertian-infrastruktur

${ }^{13}$ Ali Miftakhu Rosad, “IMPLEMENTASI PENDIDIKAN KARAKTER MELALUI MANAGEMEN SEKOLAH," Tarbawi: Jurnal Keilmuan Manajemen Pendidikan 5, no. 02 (2019): 173-190.

${ }^{14}$ Az-zarkasyi, al mantsur fil qowa'idil fiqhiyah. Juz. 1, hal. 309.
} 
Semua yang mengambil kebijakan terhadap orang lain haruslah ia mengambil kebijakan dengan kemaslahatan ${ }^{15}$.

Dari dua kaidah di atas ini, kita dapat menyimpulkan atas kebolehan mengambil kebijakan terhadap harta orang lain, dan dalam kaidah yang ke dua ini menunjukkan kebolehannya walaupun bukan seorang pemimpin.

\section{Syarat kebolehan bagi seorang pemimpin untuk mengolah uang rakyatnya}

Dalam kaidah yang sudah dipaparkan di atas, dapat kita petik pemahaman bahwa untuk mengolah dan mengambil kebijakan dari uang rakyat haruslah diiringi dengan beberapa syarat ${ }^{16}$. Karena secara logika, orang yang bukan merupakan pemimpin harus memiliki batasan dan aturan dalam memakai dan mengolah uang orang lain. Apalagi seorang pemimpin, pastilah ada batasan dan syaratnya. Batasan dan syaratnya itu adalah:

- Harus adil.

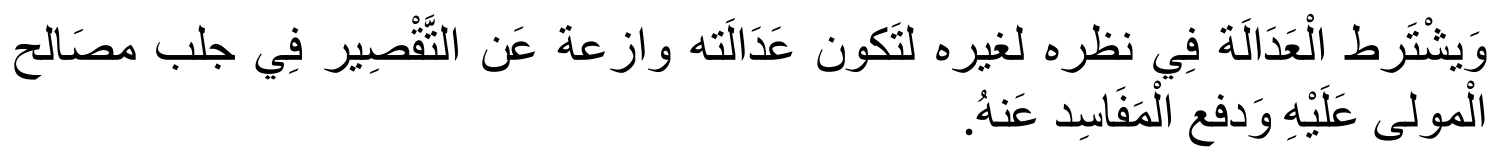

Dan disyaratkan bagi seorang pemimpin yang akan mengambil kebijakan terhadap rakyatnya harus memiliki sifat adil. Agar keadilannya tidak menimbulkan kesia-siaan tatkala ingin mendatangkan kemaslahatan dan menolak kemafsadatan ${ }^{17}$.

- Harus mendatangkan kemaslahatan.

Kemaslahatan yang dikehendaki ini sudah dicantumkan dalam kaidah sebelumnya.

\section{Kemaslahatan yang direncanakan pemerintah indonesia}

Kemaslahatan yang direncanakan pemerintah dari investasi dana haji.

1. Wakil Presiden Jusuf Kalla menjelaskan, rencana menginvestasikan dana haji untuk pembangunan infrastruktur bertujuan untuk menghindari risiko inflasi nilai rupiah terhadap dollar AS.

Menurut Kalla, dana haji yang disimpan oleh pemerintah saat ini berasal dari uang muka yang dibayarkan untuk keberangkatan pada 10 hingga 15 tahun ke depan.

Sementara, pemerintah harus membayarkan biaya haji dalam mata uang dollar AS yang dibayarkan menjelang keberangkatan.

"Dana itu tentu ada risikonya, karena ongkos hajinya itu dibayar dengan dollar. Kalau tidak diupayakan, akan inflasi dan terkait daya beli, maka harus diinvestasikan ke proyek yang menguntungkan yang juga umumnya terkait dengan dollar," ujar Kalla, di Universitas Muhammadyah Makassar, Sulawesi Selatan, Jumat (28/7/2017).

2. meningkatkan kemaslahatan ekonomi umat.

\footnotetext{
${ }^{15}$ As-subkiy, al- asybahu wan nadzo'ir. Juz. 1, hal. 310.

${ }^{16}$ SEMM Kasmir, "Bank Dan Lembaga Keuangan Lainnya," Edisi revisi (2014).

${ }^{17}$ Iz- addin bin abdis salam, Al-fawaid fi ikhtisoril maqosid, hal. 82.
} 
3. memperbaiki infrastruktur.

4. meningkatkan kualitas pelayanan.

5. Menurut wakil presiden yusuf Kalla, pemerintah memilih menginvestasikan dana haji di bidang infrastruktur karena dinilai lebih menguntungkan, misalnya pembangunan jalan tol. Jika dihitung per tahun, keuntungan yang dihasilkan bisa mencapai 15 persen.

"Katakanlah jalan tol, kalau keuntungannya saja 15 persen per tahun akan lebih tinggi dari inflasi. Harus diinvestasikan ke lebih tinggi dari inflasi kalau tidak akan bangkrut bisa-bisa tidak naik haji. Itu alasannya," ujar dia.

Dari semua kemaslahatan dan syarat yang telah ada ini menunjukkan kebolehan investasi dana haji untuk pembangunan infrastruktur. Karena jika kita lihat dari sudut kebolehan pemimpin mengolah uang dan harta rakyat sudah dibahas dan dijelaskan sejak lama oleh ulama. Begitu juga dengan syaratnya, syarat yang dikemukakan ulama sudah mengena dengan apa yang ada dalam pemerintahan indonesia ini ${ }^{18}$.

Syarat adil yang dikehendaki syara' sudah ada dan sudah didapati dari pemimpin kita, yang merupakan presiden di negara ini. Seperti syarat adil, sudah dimaklumi bahwa pemimpin indonesia sudah layak untuk dikatakan adil. Tak lupa juga dari segi kemaslahatan, tentu saja pembangunan infrastruktur di negara ini akan menghasilkan kemaslahatan, bahkan jika kita tinjau terhadap apa yang dikatakan presiden indonesia dapatlah kita menyimpulkan bahwa kemaslahatan itu sendiri merupakan tujuan utama dari pembangunan infrastruktur ini.

Namun, ada yang perlu kita kaji lebih dalam lagi terhadap kebijakan pemerintah yang ingin mengolah dan menginvestasikan dana haji ini untuk pembangunan infrastruktur di indonesia ${ }^{19}$.

a. Kemaslahatan yang dihasilkan dari pembangunan infrastruktur.

Kemaslahatan yang dikehendaki pasti adanya, tidak diragukan lagi pasti ada keuntungan yang amat besar bila dana haji yang ada digunakan untuk pembangunan infrastruktur seperti tol. Namun ada beberapa pertanyaan yang mungkin dikemukakan dalam masalah ini, pertanyaan yang sangat erat kaitannya dengan rencana pemerintah indonesia ini. Pertanyaan itu adalah :

1. Kemaslahatan dan manfaat yang dihasilkan dari investasi ini kepada siapakah kembalinya?

Untuk mendekati pemahaman dalam pertanyaan ini, ada baiknya kita kembali kepada beberapa dalil dan kaidah yang ada kaitannya dengan masalah ini. Seperti :

- Kutipan dari imam syafi'i.

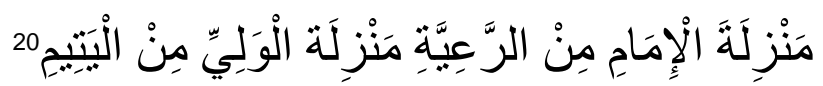

Kedudukan pemimpin terhadap rakyatnya menempati posisi wali terhadap anak yatim.

\footnotetext{
${ }^{18}$ Suhrawardi K. Lubis, Hukum Ekonomi Islam, 3rd ed. (Jakarta: Sinar Grafika, 2004).

${ }^{19}$ Abd Kadir Arno, "PENYUSUNAN ANGGARAN PERSPEKTIF FIQHI ANGGARAN HUKUM EKONOMI SYARIAH," Al-Amwal: Journal of Islamic Economic Law 1, no. 1 (2016): 30-40.

${ }^{20}$ Dr. Muhammad sodqiy al-ghaziy, al wajiz fi idohi qowaidi fiqhil kuliyyah, juz. 1, hal 347.
} 
- Dalam satu atsar berbunyi:

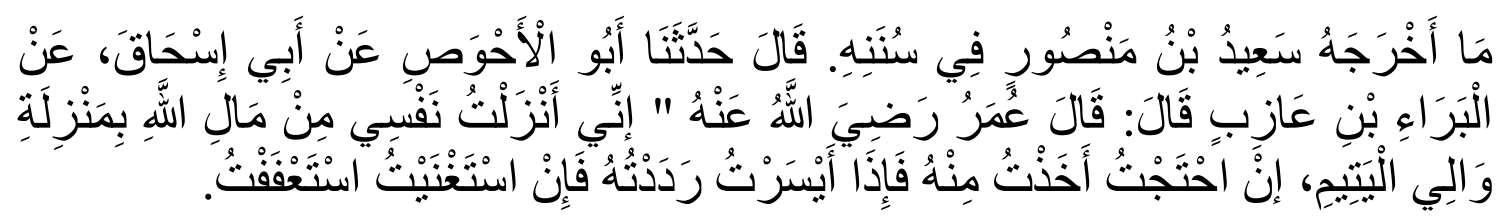

Dikeluarkan oleh said bin mansur dalam kitab sunannya. Ia berkata, abu al-ahwash menyampaikan kepada kami dari abi ishak, dari barra' bin 'azib ia berkata : umar r.a. berkata : sesungguhnya aku tempatkan diriku terhadap harta Allah swt di posisi wali bagi anak yatim, jika aku butuh akan aku ambil uang itu, dan apabila sudah lapang akan kubayar, dan jika aku sudah tidak butuh akan aku akan minta maaf ${ }^{11}$.

Dalam pembangunan jalan tol, misalnya. Pembangunan tol ini akan menghasilkan manfaat, yang manfaat itu akan kembali bukan hanya kepada calon jamaah haji, melainkan kepada umat islam lainnya, bahkan akan kembali kepada orang yang tidak beragama islam.

Perkataan umar r.a. di atas mengandung metode analogi. Yaitu menyamakan kedudukan pemimpin terhadap rakyatnya dengan kedudukan seorang wali terhadap harta anak yatim. Sebagaimana kita ketahui bahwa seorang yang menjadi wali bagi anak yatim boleh mengambil kebijakan dan mengolah semua harta dari anak yatim, namun dengan syarat harta tersebut tidak boleh sampai menghasilkan kemafsadatan dan harus menghasilkan kemaslahatan. Setelah itu, syarat keduanya adalah kemaslahatan yang ada dari proses kebijakan itu haruslah kembali kepada anak yatim tersebut, tidak boleh kembali kepada orang lain.

Jika sudah seperti ini keadaannya, maka pantaslah kita mengharuskan kemaslahatan yang kembali kepada calon jamaah haji, tidak boleh kembali kepada selain calon jamaah haji, apalagi kepada orang non islam. Sebagaimana wali hakim tidak boleh memberi kemaslahatan hasil dari anak yatim kepada orang lain.

Pada dasarnya, pembangunan infrastruktur di negara indonesia ini akan kembali kepada semua penduduk negeri ini, baik muslim ataupun non muslim, karena pada hakikatnya penduduk negara indonesia ini bukan hanya orang muslim, melainkan diisi dengan beberapa agama yang bercampur di dalamnya.

Mungkin sejenak ada pertanyaan yang menggelumit di fikiran kita, “bukankah kemaslahatan itu kembali juga kepada calon jamaah haji?". Memang benar, kemaslahatan itu kembali kepada jamaah haji juga. Hanya saja, jika kemaslahatan itu dikehendaki untuk bersama maka selayaknya modal yang digunakan tidak diambil dari harta sepihak atau beberapa golongan saja. Apalagi pemilik dana yang sepihak itu sebenarnya masih memiliki hajat yang sangat besar. Sebaiknya modal dan dana yang digunakan adalah dana yang sudah terkumpul di suatu negara tersebut, bukan melalui pengambilan dana sebagian penduduknya. Pendek kata, jika untuk kemaslahatan bersama maka gunakanlah dana dari modal bersama, dan untuk kemaslahatan sendiri maka gunakanlah modal sendiri, tidak sebaliknya.

${ }^{21}$ As-suyuthi, al-asybahu wan nadzo'ir, hal. 121. 


\section{Fajri Syahroni Siregar}

Investasi Dana Haji untuk Pembangunan......

2. Kemaslahatan yang dimaksudkan pemerintah indonesia benarkah adanya? Kemaslahatan yang dimaksud dalam kajian fiqih islam memiliki kriteria dan syarat yang harus dipenuhi, karena kemaslahatan tidak hanya bisa dikatakan kemaslahatan jika tidak memenuhi syarat seperti:

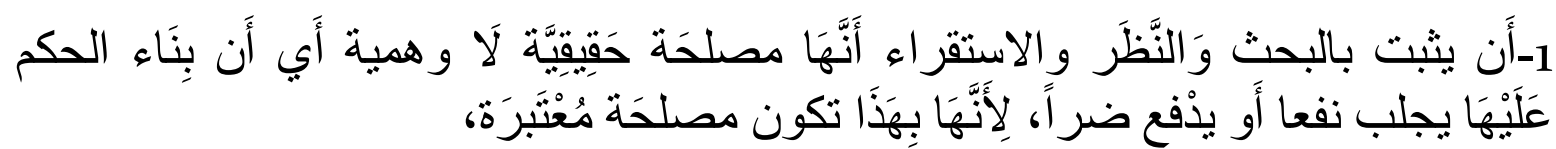

Kemaslahatan itu datang dengan dibahas dan penelitian, dan dengan teori induksi bahwa maslahat yang dikehendaki adalah maslahat yang benar adanya, bukan maslahat yang diperkirakan atau disangka-sangka. Maksudnya, membina suatu hukum atasnya akan mendatangkan kemaslahatan atau menolak kemafsadatan. Karena dengan cara yang seperti ini akan dijumpai kemaslahatan yang dianggap sah oleh syariat. ${ }^{22}$

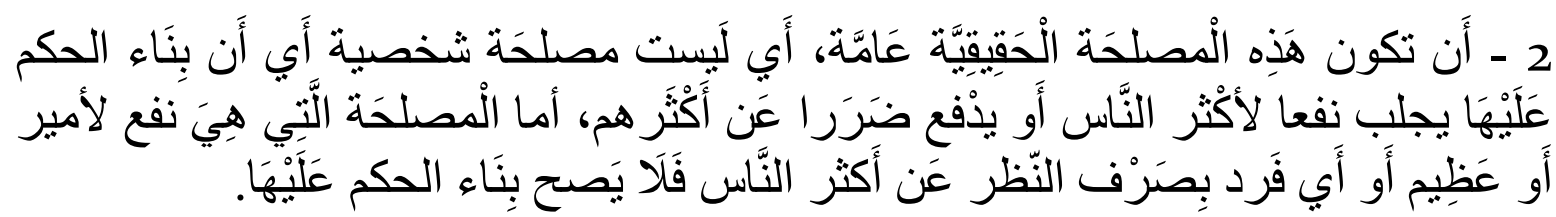

Kemaslahatan yang dikehendaki haruslah kemaslahatan yang pasti dan bersifat umum. Maksudnya, bukan merupakan kemaslahatan pribadi, artinya, pendatangan kemaslahatan dan penolakan kemafsadatan tidak dimaksud untuk melebihkan suatu golongan atas golongan yang lainnya. Adapun kemaslahatan yang ada menfaatnya utk pemimin atau org terhormat atau seseorang dengan tanpa memandang kepada kebanyakan orang maka tidak sah membina hukum dengannya.

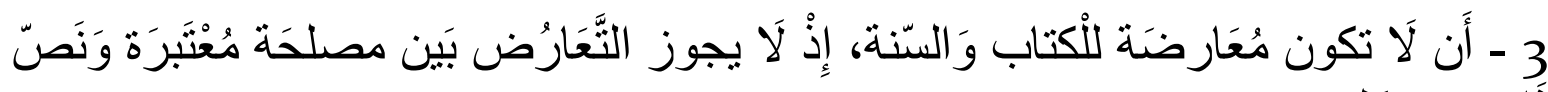

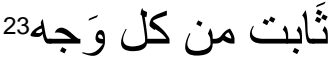

Kemaslahatan yang dikehendaki bukanlah suatu kemaslahatan yang bertentangan dengan al qur'an dan sunnah. Karena tidak boleh ada kontra antara maslahat yang mu'tabar dan nash (al qur'an dan sunnah) ditinjau dari segi manapun.

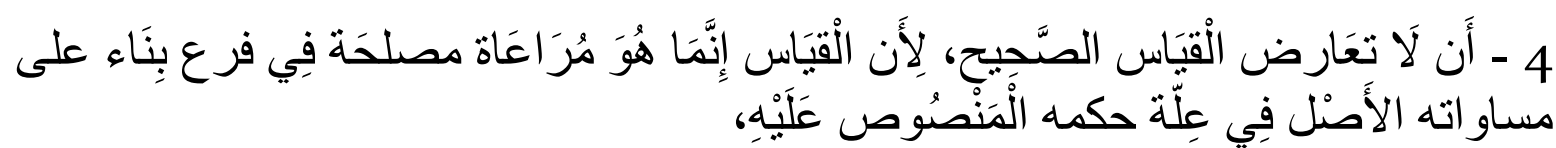

Kemaslahatan yang dikehendaki itu tidak boleh menentang qiyas yang shahih, karena qiyas diwujudkan untuk menjaga kemaslahatan di cabang hukum karena ada persamaan pada illat antaranya dengan hukum yang asli. ${ }^{24}$

\section{5- عدم تفويتها مصلحَة أهم مِنْهَا أَو مُسَاوِيَة لَهَا.}

\footnotetext{
${ }^{22}$ Muhammad tohir hakim, ri'ayatul maslahah wal hikmatu min tasyri'i nabiyyir-rohmah, hal. 239 Nur ad- diin, ilmul maqoshid asy-syar'iyah, juz 1, hal 98.

${ }^{23}$ Ali muhammad jarisyah, al maslahah almursalah, muhawalatan libastiha wa nadzrotin fiha, juz 1, hal 44.

${ }^{24}$ Muhammad tohir hakim, ri'ayatul maslahah wal hikmatu min tasyri'i nabiyyir-rohmah, hal.243
} 


\section{Fajri Syahroni Siregar}

Investasi Dana Haji untuk Pembangunan......

Kemaslahatan yang dikehendaki itu tidak menghilangkan maslahat yang lebih penting darinya, atau maslahata yang sama penting dengannya. ${ }^{25}$

Pertanyaan yang akan dikemukakan dalam masalah ini adalah mungkinkah suatu kemaslahatan akan terwujud dalam waktu cepat?. Pertanyaan ini timbul karena suatu perkiraan, apakah kemaslahatan yang dikehendaki akan terealisasi sebelum jama'ah haji berangkat ke tanah suci.

Bila kita kaitkan dengan syarat maslahah yang pertama, maka akan kita dapatkan bahwa nantinya keuntungan dan manfaat yang diangankan dan diimpikan pemerintah bisa tidak terwujud dengan lambatnya perkembangan dan pembangunan infrastruktur di suatu negara. Dan akhirnya bisa terjadi seorang yang ingin berangkat haji akan terkendala karena uang yang ditabung telah diinvestasikan dan belum menuai keuntungan.

Mungkin saja orang berfikir bahwa saat investasi belum menuai keuntungan, maka dana yang akan digunakan adalah dana yang diambil dari uang lainnya. Dengan kata lain, uang yang akan digunakan untuk memberangkatkan jamaah haji adalah uang dari jamaah haji yang lain. Ataupun dengan uang dari investasi yang lain, dalam kata lain, dari suatu investasi akan timbul investasi lainnya, dari suatu pemutaran uang akan timbul pemutaran uang lainnya.

Namun jika kita tinjau terhadap fatwa menteri agama yang mendeskripsikan bentuk uang tersimpan itu adalah "wadi'ah" (titipan) maka akan kita dapati bahwa cara yang seperti ini tidak sah dan tidak dibenarkan, karena pada dasarnya orang yang memegang titipan itu hanya memiliki pengembanan amanah, bukan yang lainnya, sehingga ia dapat memutar dan mengolah uang dari orang lain ke orang yang lainnya.

3. Kemaslahatan yang dikehendaki pemerintah itu bagaimana hasilnya? (Tinjauan terhadap kemaslahatan yang dikemukakan wakil presiden Jusuf Kalla).

Yusuf kalla memberikan penegasan bahwa dana haji yang digunakan untuk menghindarkan dana haji dari inflasi. Maka dari ini dapat kita ambil kesimpulan bahwa apa yang direncanakan pemerintah ini merupakan kemaslahatan yang dimulai dengan dar'ul mafasid, dan dar'ul mafasid sangat di terima dalam khazanah keilmuan islam.

Namun di balik itu ada yang harus kita perhatikan bahwa umat islam yang merupakan calon haji tersebut juga masih mengalami kekurangan, seperti kurangnya sarana prasarana haji. Seperti hotel dan transportasi yang sangat dibutuhkan di tanah suci makkah. Maka dari konteks ini ada benturan diantara dua kemafsadatan. Kemafsadatan yang pertama timbul dari inflasi yang diawali dari pengawasan terhadap inflasi, sedangkan kemafsadatan yang kedua adalah kurangnya fasilitas yang dibutuhkan jamaah haji di tanah suci makkah.

Untuk mendalami pengkajian tentang kemafsadatan ini ada baiknya jika didekatkan dengan kaidah fiqih yang berbunyi :

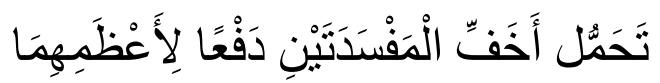

${ }^{25}$ Muhammad hasan abdul ghoffar. Taysiru ushulil fiqhi lilmubtadi'in, hal. 12 


\section{Fajri Syahroni Siregar}

Investasi Dana Haji untuk Pembangunan......

Menanggung mafsadat yang paling ringan untuk menolak masfsadat yang lebih besar ${ }^{26}$

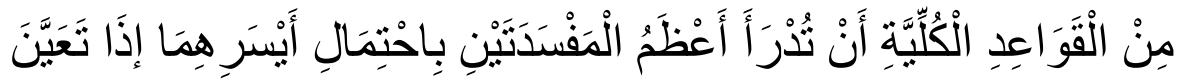

Yang termasuk kaidah kulliyah salah satunya adalah. Membuang kerusakan yang lebih besar dengan menganggung kerusakan yang paling ringan. ${ }^{27}$

Dalil bagi kaidah ini adalah suatu hadits yang pernah terjadi di zaman rasulullah saw. Yang berbunyi :

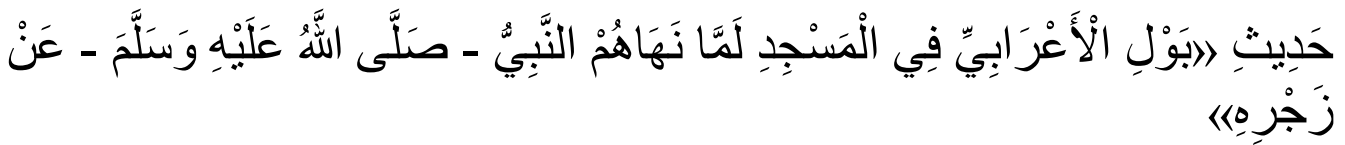

Hadits tentang kencingnya orang arab badui di masjid, tatkala rasulullah saw melarang sahabat dari menghardiknya. ${ }^{28}$

Memang besar kemaslahatan dan keuntungan yang dihasilkan dari pembangunan infrastruktur ini, namun di balik itu ada yang harus ditelaah dan di kaji ulang dari permasalahan ini. Yaitu tentang kebutuhan dan keperluan jamaah haji yang selama ini melanda para calon jamaah haji di indonesia. Pembangunan yang seharusnya direalisasikan di negara arab saudi sana seharusnya lebih diutamakan dari pada pembangunan yang sebenarnya penduduk dan pengolahnya masih mampu untuk mewujudkannya.

Sebenarnya, para calon jamaah haji yang ingin menyempurnakan rukun islamnya tidaklah semuanya merupakan orang menengah ke atas, atau orang kaya, melainkan sebagian dari mereka adalah orang menengah ke bawah, berbeda dengan orang yang akan merasakan manfaat dari pembangunan infrastruktur ini, kebanyakan dari mereka adalah non islam yang berada di posisi menengah ke atas dalam masalah ekonomi.

Untuk menjelaskan korelasi antara masalah mafsadat dari pembangunan ini dengan kaidah di atas, kami jelaskan beberapa penjelasan sebagai berikut:

\section{Mafsadat yang pertama :}

Mafsadat yang mengarah kepada inflasi bisa saja diaplikasikan terhadap investasi dana haji ini. Karena kemafsadatan ini dapat diatasi dari dana haji. Dan kemaslahatannya akan kembali kepada calon jamaah haji itu sendiri. Namun, dibalik itu ada yang harus kita kaji dari investasi ini. Investasi yang dilatar belakangi inflasi ini tidak hanya mengarah kepada kemaslahatan calon jamaah haji semata. Melainakan ada kemaslahatan lain yang mengarah kepada kemaslahatn ini, seperti pembangunan infrastruktur. Infrastruktur yang dibangun denan dana ini akan memiliki bekas. Dan manfaatnya tidak hanya kembali kepada jamaah haji,

\footnotetext{
${ }^{26}$ Iz- ad-din bin abdis- salam, Qowaidul ahkam fi masholihil anam, juz. 1, hal. 46. Az-zarkasyiy, tasyniful masami' bisyarhi jam'il jawami'. Juz 1, hal 240.

${ }^{27}$ Al-mantsur fil qowa'idil fiqhiyah, juz. 1, hal 348.

Az-zarkasyiy, al-bahrul muhith fi ushulil fiqh, juz. 6, hal. 317.

${ }^{28}$ Ibid, hal. 349.
} 
melainkan kembali kepada orang yang bukan calon jamaah haji, bahkan kembali kepada orang non muslim.

\section{Mafsadat yang kedua :}

Mafsadat yang kembali kepada prosedur dan pembangunan hotel dan transportasi, sarana prasarana bagi jamaah haji di makkah. Kemafsadatan yang diatasi dalam konteks ini tidak lari dari urusan jamaah haji dengan apa yang dibutuhkan mereka. Dan jelas pula bahwa semuanya itu tidak mungkin diambil oleh orang yang bukan merupakan calon haji. Karena orang yang non muslim tidak mungkin melaksanakan ibadah haji ${ }^{29}$.

Jika kita bandingkan keduanya, maka akan dapat kita ambil kesimpulan bahwa kemafsadatan yang kedua lebih besar dari pada kemafsadatan yang pertama. Karena kemafsadatan yang kedua berkaitan dengan sistem dan sarana-prasarana, sedangkan kemafsadatan yang didasarkan kepada inflasi dapat dikembalikan kepada calon jama'ah haji. Dan jamaah haji akan membayar dengan harga yang sesuai pada zaman itu. Sementara kemafsadatan yang terjadi di tanah haram sana, dan kembali kepada sarana-prasarana yang berkaitan dengan jmaah haji tidak mungkin diselesaikan oleh jamaah haji. Karena jamaah haji tidak mungkin menyelesaikan masalah transportasi dan sarana seperti pembangunan hotel. Tidak mungkin jamaah haji membangun hotel dan segala yang mereka butuhkan di makkah ${ }^{30}$.

4. Komparasi antara maslahat yang dikehendaki presiden dengan maslahat yang dikehendaki jama'ah haji.

Jokowi menjelaskan, pemerintah memilih menginvestasikan dana haji di bidang infrastruktur karena dinilai lebih menguntungkan, misalnya pembangunan jalan tol.Jika dihitung per tahun, keuntungan yang dihasilkan bisa mencapai 15 persen.

Namun, bila kita bandingkan dengan kemaslahatan yang seharusnya terjadi di tanah makkah sana seharusnya sudah terealisasi dengan baik. Kemaslahatan yang terjadi di arab saudi sana akan lebih baik dari pada yang direncanakan pemerintah indonesia. Kenapa, karena sejatinya jika hotel sebagai tempat tinggal, kendaraan, dan makanan yang dibutuhkan jamaah di sana, maka keuntungan yang diharapkan pemerintah tidak akan dibutuhkan lagi, karena tempat tinggal tidak harus kita sewa lagi, karena sudah kita miliki, begitu juga dengan transportasi, jika semua sudah dimiliki maka akan lebih mudah ke depannya bagi jama'ah haji kita.

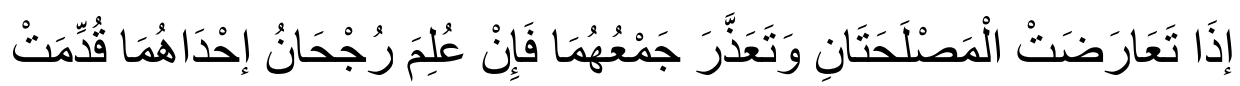

Apabila bertentangan dua kemaslahatan jika diketahui mana yang lebih kuat diantara keduanya maka dahulukanlah maslahat yang lebih kuat. ${ }^{31}$

Jika jauh kita meninjau dan mengambil relevansi dari kaidah ini, maka dapatlah kita menyimpulkan bahwa kebaikan dan manfaat yang dikehendaki dari kaidah ini lebih mengarah kepada kemaslahatan yang dibutuhkan calon jama'ah haji.

\footnotetext{
${ }^{29}$ Nasrun Haroen, Fiqih Muamalah (Jakarta: Gaya Media Pratama, 2007).

${ }^{30}$ Adiwarman A. Karim, Bank Islam: Analisis Fiqih Dan Keuangan (Jakarta: Raja Grafindo, 2004).

${ }^{31}$ Iz-addin bin abdis-salam, Qowaidul ahkam fi masholihil anam, juz 1, hal. 60.
} 
Mari kita meninjau kaidah ini:

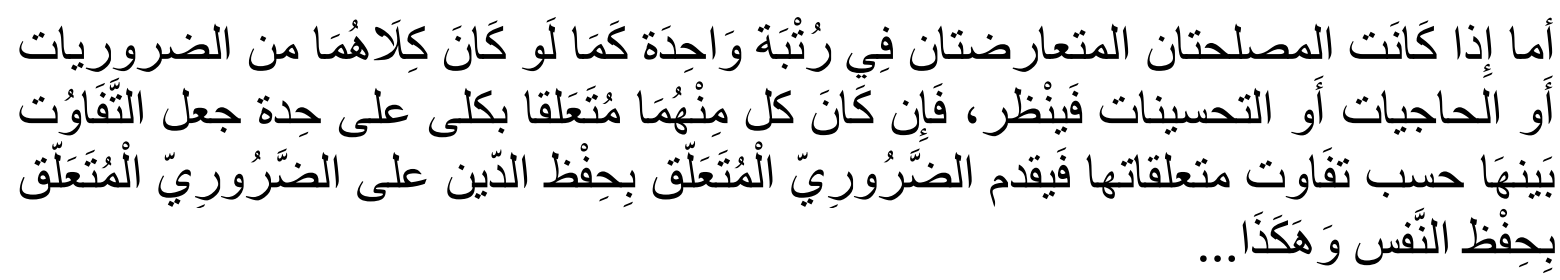

Jika didapati dua kemaslahatan yang bersebrangan dan menempati kedudukan yang sama, seperti kalau keduanya menempati kebutuhan dharurat (primer) atau hajiat (sekunder) atau tahsiniat( tertier). Maka hendaknya diteliti, jika keduanya berkaitan dengan kebutuhan yang menyeluruh secara jelas, maka jadikanlah selisih yang terjadi diantara keduanya seperti selisih terhadap keterkaitan kedunya. Maka dahulukanlah dharurat yang berkaitan dengan agama dari pada dharurat yang berkaitan dengan diri. $^{32}$

Maslahat yang ada pada konteks ini pada dasarnya terbagi dalam dua maslahat :

Maslahat yang pertama, yaitu maslahat yang direncanakan presiden jokowi untuk membangun infrastruktur seperti jalan tol, jika dilihat, maslahat yang akan ditimbulkan dari pembangunan ini bersifat dhoruri, dan sangat penting mengingat pembangunan infrastruktur seperti tol merupakan pembangunan yang sangat dibutuhkan, maka dapatlah kita golongkan ia ke dalam maslahat yang kembali kepada an-nafs (diri/jiwa) karena semua orang akan merasakannya untuk kebutuhan pribadi.

Maslahat yang kedua, yaitu maslahat yang diperlukan para calon jama'ah haji, jika dilihat maslahat yang ini akan kembali kepada agama, karena sebenaranya para calon jama'ah haji membutuhkan sarana prasarana seperti hotel dan transportasi, begitu juga dengan makan pokok yang jika semua itu tidak ada maka tidak akan terwujud impian mereka untuk menyempurnakan rukun agamanya.

Maka jelaslah dari kaidah ini menunjukkan bahwa kemaslahatan yang berkaitan dengan ibadah haji lebih utama daripada kemaslahatan yang ingin diwujudkan di negara indonesia ini. Semua itu dikarenakan kemaslahatan haji merupakan kemaslahatan yang berkaitan dengan agama, sedangkan kemaslahatan infrastruktur ini merupakan kemaslahatan yang berkaitan dengan diri atau jiwa.

Kemungkinan seseorang (pemerintah ataupun tidak) mengolah dan mengambil kebijakan terhadap uang orang lain sementara uang yang semestinya dikeluarkan masih ada

Pertanyaan ini didapat melalui pengamatan terhadap konteks yang terjadi di indonesia ini. Negara indonesia merupakan negara yang kaya, rakyatnya juga merupakan rakyat yang taat membayar pajak ${ }^{33}$. Maka dari itu dapat kita simpulkan

\footnotetext{
${ }^{32}$ Muhammad thohir hakim. Ri'ayatul maslahah wal hikmatu min tasyri'i nabiyyir-rahmah, hal. 245. Walid bin rosyid sa'idan, talqihul afhamil aliyah bisyarhil qowa'idil fiqhiyah, juz 3, hal 12.

${ }^{33}$ ABDUL MUIN, “NOTARY ROLE IN MAKING AGREEMENT DEED AKAD QARD IMPLEMENTATION AND FINANCING IN IJARAH IN HAJJ BAILOUT BANK SYARIAH MANDIRI (PERAN NOTARIS DALAM PEMBUATAN AKTA PERJANJIAN PELAKSANAAN AKAD QARD WAL IJARAH PADA PEMBIAYAAN DANA TALANGAN HAJI DI BANK SYARIAH M," Risâlah, Jurnal Pendidikan dan Studi Islam 5, no. 1 (2019): 19-30.
} 
bahwa sebenarnya banyak uang untuk dana infrastruktur di negara kita ini. Jika uang itu digunakan untuk pembangunan infrastruktur tentunya akan mencukupi, dan sebenarnya memang seperti itulah prosedur yang harus dilakukan pemerintah.

Jadi, sebenarnya ada dua sisi yang harus diamati dalam konteks ini. Yaitu :

- Sisi yang pertama terdapat pada keuangan negara telah disimpan oleh orang yang telah dipercaya untuk menghimpun dan mengolahnya sesuai undangundang yang telah ditetapkan. Kegunaannya akan mengarah kepada seluruh penduduk, tanpa ada pengecualian.

- Sisi yang kedua terdapat pada uang sebagian penduduk yang ditujukan untuk ibadah yang merupakan penyempurnaan rukun agama mereka.

Jika kita lihat dari sisi pertama akan tampak jelas bahwa ia merupakan simpanan di suatu negara yang seharusnya digunakan dalam pembangunan infrastruktur ini. Sedangkan uang yang terletak di sisi ke dua akan didapati ketidak cocokan, dikarenakan tujuan yang sangat berbeda dengan uang negara yang seharusnya digunakan untuk infrastruktur.

Uang yang ada di dalam simpanan suatu negara tidak akan pernah habis. Mengapa, karena tak akan ada orang yang berhenti membayar pajak, juga masih banyak hasil negara yang dapat dimasukkan ke dalam kas negara ini.

Jika sudah demikian adanya, maka dari sinilah timbul pertanyaan mungkinkah pemerintah mengambil uang dana haji untuk pembangunan ini, sementara masih ada uang yang pantas digunakan untuk pembangunan ini.

Analoginya akan diambil dari pernyataan umar r.a.

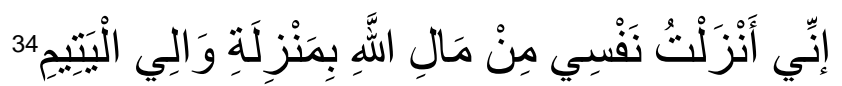

Aku menempatkan diriku terhadap harta Allah di posisi wali bagi anak yatim.

Maka jika si wali masih memiliki uang atau harta yang dapat digunakan untuk keperluannya dan keperluan orang yang lain dari anak yatim yang ia jaga, pastilah tidak dapat dibenarkan mengambil uang anak yatim, bagaimana tidak, sedangkan si wali yang menjaga anak yatim masih memiliki uang sendiri, maka tidak akan mungkin dan tidak bisa dibenarkan untuk mengambil harta anak yatim. Walaupun kepentingannya akan kembali untuk semua orang tanpa terkecuali.

Mungkin kita akan bertanya,

1. bukankah si anak yatim sendiri akan mendapatkan manfaat dari tasharruf itu, dan dalam konteks dana haji ini bukankah manfaatnya kembali juga kepada calon jamaah haji.

2. Bukankah si anak yatim sendiri juga merupakan orang yang dibawah pimpinan walinya, sebagaimana orang lain yang bukan anak yatim juga termasuk orang yang diasuh sang wali tersebut. Dan dalam konteks dana haji ini, bukankah calon jamaah haji juga merupakan warga negara indonesia yang seharusnya memberikan pemasukan untuk pembangunan.

\footnotetext{
${ }^{34}$ Asy-syatibiy, al muwafaqot, juz. 2, hal 324.

Ahmad bin muhammad makkiy, ghomzu 'uyunil basho'ir fi syarhil asybah wan-nadzo'ir, juz 1, hal. 369.
} 


\section{Fajri Syahroni Siregar}

Investasi Dana Haji untuk Pembangunan......

Memang benar, pembangunan infrastruktur ini tetap kembali kepada uang calon jama'ah haji yang juga merupakan penduduk indonesia, dan memang benar bahwa calon jama'ah haji ini juga harus memberikan pemasukan material terhadap pembangunan ini. Namun, untuk pembangunan ini sudah ada sistem yang diatur oleh undang undang negara, dan pada hakikatnya, calon jama'ah haji juga ikut serta dalam pembangunan infrastruktur di negara indonesia yang tercinta ini, seperti pembayaran pajak.

Jika sudah demikian maka tidak bisa disamakan kedudukannya dengan uang yang dikumpulkan jama'ah haji untuk kebutuhan ibadah mereka. Dan memang selayaknya tidak digunakan uang yang digunakan untuk ibadah itu kepada fungsi yang lainnya. Uang negara untuk negara, uang ibadah untuk ibadah.

Tatbiqh ayat ini terhadap permasalahan investasi adalah, jika sang pemimpin mengambil uang jama'ah haji untuk keperluan yang lain dari ibadah haji, maka kebijakan ini akan berdampak manfaat kepada yang selain jamaah haji, seperti pemborong yang akan mengerjakannya, para pembesar yang akan merencanakan proyek ini akan mendapatkan keuntungan dari itu semua, dan semua keuntungan itu diambil dari harta orang yang tidak dimaksudkan untuk kepentingan infrastruktur ini.

Semua itu karena dalam ayat ini mengandung lafadz jama' yang dapat dianggap sebagai lafadz 'amm (umum).

Ibnu abbas, hasan dan qatadah berkata bahwa ayat ini turun pada masalah wadi'ah (titipan) bagi seorang lelaki atas orang lain, sementara tidak ada bukti bagi si pemilik wadi'ah ${ }^{35}$. Maka dari itu, di halaman selanjutnya akan kami bahas masalah wadi'ah ini sesuai dengan penjelasan menteri agama.

\section{Penjelasan fatwa MUI tentang investasi dana haji}

Dana haji yang dikumpulkan apakah ditidurkan saja atau diproduktifkan. Setelah disepakati, dana calon jemaah haji tersebut boleh diproduktifkan tapi harus memenuhi empat syarat yang tertuang dalam fatwa MUI.

1. Boleh ditasharrufkan tapi harus dipastikan jenis usahanya memenuhi prinsip prinsip syari'ah.

2. Terkait dengan prudensialitas atau aman, logikanya seperti pengelolaan dana wakaf, yakni tidak boleh berkurang, tapi harus tetap berkembang dan memiliki nilai manfaat.

3. Ada manfaatnya. Kalau ada manfaatnya baik kepada jamaah haji untuk kepentingan kemashlahatan jamaah dan kemaslahatan umat islam. ( tambahan dariku. Karena investasi yang dijalankan pemerintah adalah penanaman modal, nah penanaman modal tidak akan mungkin bisa terwujud bila si pemilik modal tidak mendapatkan keuntungan secara utuh, melainkan keuntungan itu sendiri dibagi dan diberikan kepada orang yang non islam, sementara orang yang non islam itu sendiri tidak memberikan tenaga dalam pemutaran uang. Apalagi memberi modal.)

\footnotetext{
${ }^{35}$ Al-jurjani. Durjud duror fi tafsiril ayi was-suwar, juz. 1, hal. 291.

Abu ja'far ath-thabari, tafsir jami'ul bayan, juz 3, hal. 550
} 
Bukan investasinya, tapi hasil investasinya bisa saja diinvestasikan untuk pembangunan gedung, hasilnya baik untuk kemashlahatan sepanjang ketentuannya sesuai dengan prinsip-prinsip syari'ah.

4. Liquid. Artinya dana ini dibutuhkan dalam waktu terus menerus ${ }^{36}$.

\section{Peraturan perundang-undangan tentang dana haji.}

Pentingnya pengelolaan dana yang besar itu, maka lahir Undang-undang No.34 Tahun 2014 tentang Pengelolaan Keuangan Haji. Berdasarkan Pasal 20, pengelolaan keuangan haji dilakukan oleh Badan Pengelola Keuangan Haji (BPKH).

BPKH memiliki tugas untuk menerima, mengembangkan, mengatur pengeluaran dan bertanggungjawab atas keuangan haji yang berhasil dihimpun. BPHK juga bertugas untuk mengurus investasi keuangan haji yang sesuai dengan prinsip syariah, kehati-hatian, aman dan bermanfaat. Badan ini pun berwenang untuk bekerjasama dengan lembaga lain dalam pengelolaan keuangan haji.

Wakil Ketua Komisi VIII Abdul Malik Haramain menilai, rencana pemerintah menambah manfaat dana haji yang dikelola Badan Pengelola Keuangan Haji (BPKH) untuk investasi infrastruktur bertentangan dengan Undang-undang (UU) Nomor 34 Tahun 2014 tentang Pengelolaan Keuangan Haji.

"Makanya waktu kami kemarin, uji kepatutan anggota dewan pengawas dan badan pelaksana BKPH kami sudah wanti-wanti," kata Abdul saat dihubungi CNNIndonesia.com, Jumat (28/7). Menurutnya, UU tersebut harus jadi acuan BPKH meski diberi kewenangan mengelola dana haji. Jika rencana itu ditujukan untuk peningkatan pelayanan fasilitas haji, kata dia, tidak masalah. "Kalau infrastruktur tidak boleh, tidak bisalah. Ini penggunaanya untuk kemaslahatan umat," katanya. Selain itu, Abdul mengingatkan, penggunaan dana haji harus bebas resiko karena bukan uang negara. "Itu uang umat, harus dijamin keamanannya dan harus bebas resiko," ujarnya.

Mengacu Pasal 3 UU Nomor 34 Tahun 2014, menyebutkan bahwa penggunaan dana haji untuk pertama, kualitas penyelenggaraan ibadah haji, kedua, rasionalitas dan efisiensi pengunaan biaya pengelolaan ibadah haji dan ketiga, manfaat bagi kemaslahatan umat Islam.

"Yang dimaksud untuk kemaslahatan umat Islam adalah kegiatan pelayanan ibadah haji, pendidikan dan dakwah, kesehatan, sosial keagamaan, ekonomi umat, serta pembangunan sarana dan prasarana ibadah," kata dia.

\section{Hubungan antara calon jama'ah haji dengan bank penerima dana haji menurut menteri agama, serta penjabarannya.}

Menteri agama menjelaskan hubungan antara calon jemaah haji dengan bank penerima setoran akadnya ada dua opsi, yaitu :

1. Akad wadi'ah. Artinya dana itu nitip saja sehingga tidak ada faidah. Tidak ada bagi hasil ${ }^{37}$.

2. Akad mudharabah, yakni saat calon jemaah haji mencapai 25 juta maka dapat nomor porsi dan masuk dalam waiting list.

\footnotetext{
${ }^{36}$ https://nasional.tempo.co/read/896291/mui-ajukan-empat-syarat-pengembangan-dana-haji

${ }^{37}$ Quraish Shihab, Tafsir Al-Misbah, Pesan, Kesan Dan Keserasian Al-Qur'an (Jakarta: Lentera Hati, 2002).
} 


\section{Fajri Syahroni Siregar}

Investasi Dana Haji untuk Pembangunan......

Sebelum maupun sesudah mecapai 25 juta statusnya belum billing karena belum tau berapa biaya hajinya. Uang setoran itu statusnya masih milik jamaah haji.

Untuk mendekatakan faham dalam dua opsi di atas, ada baiknya jika kedua opsi di atas diperjelas.

1. Akad wadi'ah.

Mengapa dalam akad wadiah ini tidak dibenarkan mengambil faidah. Karena sebenarnya kekuasaan si penerima wadi'ah (titipan) hanyalah amanah. Ada beberapa literatur yang menerangkan masalah ini:

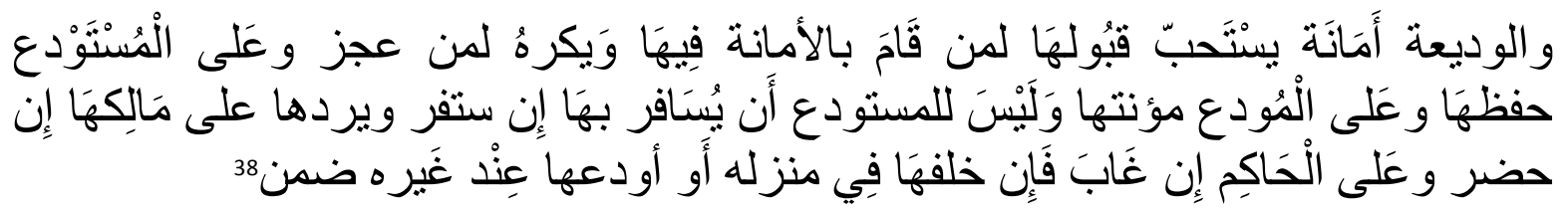

Dan wadi'ah (titipan) itu merupakan amanah, disunatkan menerimanya bagi orang yang dapat mengemban amanah dalam menjaganya, dan makruh menerimanya bagi bagi orang yang tidak sanggup, dan wajib bagi si penerima wadi'ah menyimpannya, dan bagi si penitip memberi biaya dalam menjaganya. Dan sipenyimpan titipan tersebut tidak boleh pergi membawa titipan itu, hendaknya ia mengembalikannya kepada si pemilik jia ia ada, dan kepada hakim jika si pemilik tidak ada di tempat. Dan jika ia tinggalkan di rumahnya atau ia titipkan ke orang lain maka ia wajib menjaminnya.

$$
\text { و إن أخرجها لينتفع بها ضمنها لأنه تصرف في الوديعة بما ينافي مقتضاها فضمن به }
$$

Dan apabila si penjaga titipan mengeluarkan harta titipan itu untuk mengambil manfaat darinya maka ia wajib menjaminnya (bertanggung jawab), karena ia mengolah (mengambil kebijakan) menggunakan cara yang kontra de tuntutan titipan itu sendiri ${ }^{39}$.

$$
\begin{aligned}
& \text { أما الاحكام فقد اتفق الائمة كلهم على أن الوديعة من القرب المندوب إليها. }
\end{aligned}
$$

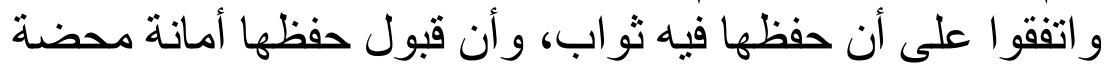

Adapun hukum dari wadiah, sesungguhnya ulama telah sepakat bahwa wadi'ah merupakan jalan mendekatkan diri (kepada allah) yang disunatkan, dan ulama telah sepakat bahwa menyimpannya merupakan pahala, dan menerima titipannya merupakan amanah semata-mata ${ }^{40}$.

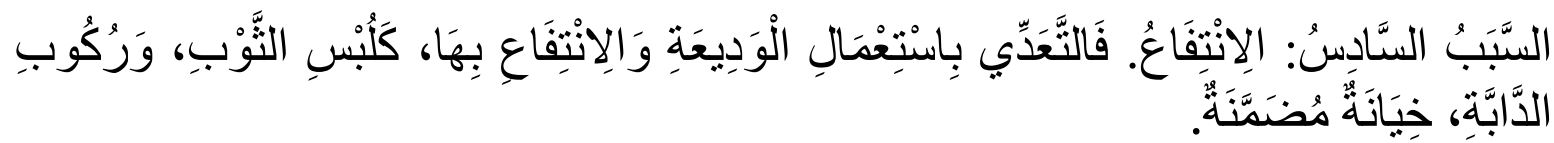

Sebab (menjamin karena menyalahai tuntuan wadiah) yang ke enam adalah: mengambil manfaat. Pelanggaran dengan menggunakan barang titipan dan

\footnotetext{
${ }^{38}$ Al-mawardi, al iqna', hal. 113

${ }^{39}$ Asy-syairozi. Al-muhadzdzab fi fiqhil imam asy-syafi'i, juz. 2, hal. 185.

${ }^{40}$ An-nawawi, al-majmu' syarhul muhadzdzab, juz. 14, hal, 174.
} 


\section{Fajri Syahroni Siregar}

Investasi Dana Haji untuk Pembangunan......

mengambil manfaat darinya seperti memakai baju titipan dan menunggangi hewan adalah suatu pengkhianatan yang harus dipertanggung jawabkan. ${ }^{41}$

2. Akad mudharabah.

Adapun akad mudharabah seperti yang digambarkan menteri agama diatas merupakan gambaran yang pantas dan layak terhadap prosedur penyimpanan dana haji ini.

Kebolehan mudharabah itu telah disebutkan ulama di dalam literaturnya, seperti yang disebutkan imam al-umroni dalam kitabnya al-bayan:

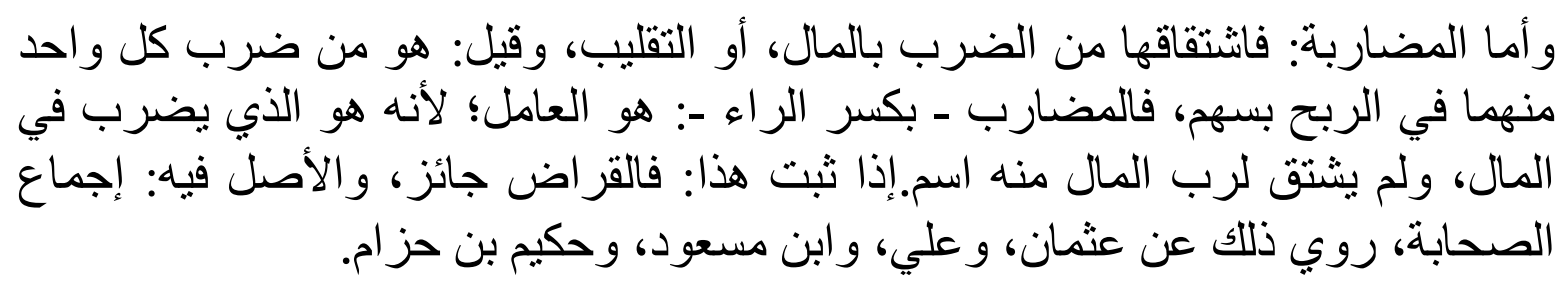

Adapun mudharabah adalah kalimat yang berubah dari bentuk asalnya yaitu pembagian dengan harta, atau mengubah, dan dikatakan bahwa mudhorobah adalah pembagian hasil dari kedua belah pihak. Maka si mudhorib adalah orang yang mengolah harta tersebut, karena dialah orang yang mengolah dengan uang, dan tidak dirubah nama dari si pemilik modal, jika sudah ditetapkan ini, maka qiradh (mudharabah) boleh. Dan asal yang membolehkannya adalah ijma' para sahabat, diriwayatkan ijma' itu dari utsman dan ali, dan ibnu mas'ud dan hakim bin hizam ${ }^{42}$.

Mudharabah mengutamakan landasan saling menguntungkan antara kedua belah pihak, maka akan timbul pertanyaan, apa keuntungan yang didapatkan si penyimpan uang dari dana haji ini jika tidak diolah?.

Sebenarnya kedua belah pihak telah mendapatkan keuntungan. Calon jamaah haji mendapatkan keuntungan dari semua yang telah ia simpan sampai ia berangkat ke tanah suci, sementara si penyimpan uang dana haji tersebut telah mendapatkan keuntungan dari apa yang dia usahakan dari transport dan kerja sama antara ia dengan beberapa perusahaan travel. Begitu juga dengan kegiatan sarana prasarana yang di siapkan di tanah suci makkah.

\section{Simpulan}

Berdasarkan hasil penelitian dan pembahasan tersebut, dapat ditarik kesimpulan sebagai berikut:

Pertama, seorang pemimpin tidak boleh menginvestasikan dana haji untuk membangun infrastruktrur, karena kemaslahatan yang diinginkan masyarakat lebih besar daripada apa yang direncanakan pemerintah.

Kedua, mungkin terwujud suatu kemaslahatan dari investasi ini, namun ada kemaslahatan yang lebih besar daripada maslahat yang direncanakan pemerintah. Ketiga, menginvestasikan dana zakat tidak dibenarkan dalam kajian hukum Islam, karena sejatinya maslahat yang diinginkan oleh pemerintah indonesia tidak sesuai dengan apa yang dikonsepkan dalam kaidah fiqih, karena hukum Islam

\footnotetext{
${ }^{41}$ An-nawawi, roudhotut-tholibin wa 'umdatul muftin, juz.6, hal. 334.

${ }^{42}$ Al-umroni, al-bayan fi madzhabil imam asy-syafi'i, juz. 7, hal. 182.
} 


\section{Fajri Syahroni Siregar}

Investasi Dana Haji untuk Pembangunan......

menginginkan kemaslahatan yang tidak menimbulkan kemafsadatan di sisi orang lain.

Keempat, Jika dibandingkan, maka kemaslahatan masyarakat indonesia lebih besar daripada kemaslahatan yang dicanangkan pemerintah.

Kelima, akad yang ada diantara kedua belah pihak lebih pantas dikatakan dengan akad wadi'ah atau akad mudharabah, atau bisa diqiyaskan dengan wakaf yang berarti bahwa pemerintah tidak boleh sedikitpun mengambil kebijakan di atas uang masyarakat itu.

DAFTAR PUSTAKA

Arno, Abd Kadir. "PENYUSUNAN ANGGARAN PERSPEKTIF FIQHI ANGGARAN HUKUM EKONOMI SYARIAH.” Al-Amwal: Journal of Islamic Economic Law 1, no. 1 (2016): 30-40.

Baharun, Hasan. "Management Information Systems in Education: The Significance of e-Public Relation for Enhancing Competitiveness of Higher Education." In Journal of Physics: Conference Series, 1175:12151. IOP Publishing, 2019.

Baharun, Hasan, Moh Tohet, Juhji Juhji, Siti Maryam Munjiat, Adi Wibowo, and Siti Zainab. "MODERNISASI PENDIDIKAN DI PONDOK PESANTREN: Studi Tentang Pemanfaatan Sistem Aplikasi Pedatren Dalam Meningkatkan Mutu Layanan Pondok Pesantren." Al-Tarbawi Al-Haditsah: Jurnal Pendidikan Islam 6, no. 1 (2021): 1-22.

Baharun, Hasan, Adi Wibowo, and Siti Nur Hasanah. "Kepemimpinan Perempuan Dalam Menciptakan Sekolah Ramah Anak.” Quality 9, no. 1 (2021): 87-102.

Haroen, Nasrun. Fiqih Muamalah. Jakarta: Gaya Media Pratama, 2007.

Karim, Adiwarman A. Bank Islam: Analisis Fiqih Dan Keuangan. Jakarta: Raja Grafindo, 2004.

Kasmir, SEMM. "Bank Dan Lembaga Keuangan Lainnya." Edisi revisi (2014).

Lubis, Suhrawardi K. Hukum Ekonomi Islam. 3rd ed. Jakarta: Sinar Grafika, 2004.

MUIN, ABDUL. "NOTARY ROLE IN MAKING AGREEMENT DEED AKAD QARD IMPLEMENTATION AND FINANCING IN IJARAH IN HAJJ BAILOUT BANK SYARIAH MANDIRI (PERAN NOTARIS DALAM PEMBUATAN AKTA PERJANJIAN PELAKSANAAN AKAD QARD WAL IJARAH PADA PEMBIAYAAN DANA TALANGAN HAJI DI BANK SYARIAH M." Risâlah, Jurnal Pendidikan dan Studi Islam 5, no. 1 (2019): 19-30.

Priyatna, Tedi. "Inovasi Pembelajaran PAI Di Sekolah Pada Era Disruptive Innovation." Jurnal Tatsqif 16, no. 1 (2018): 40.

Rosad, Ali Miftakhu. "IMPLEMENTASI PENDIDIKAN KARAKTER MELALUI MANAGEMEN SEKOLAH.” Tarbawi: Jurnal Keilmuan Manajemen Pendidikan 5, no. 02 (2019): 173-190.

Rosyad, Ali Miftakhu. "The IMPLEMENTASI NILAI-NILAI MULTIKULTURALISME MELALUI PEMBELAJARAN PENDIDIKAN AGAMA ISLAM (THE IMPLEMENTATION OF MULTICULTURALISM VALUES THROUGH LEARNING OF ISLAMIC RELIGION EDUCATION).” Risâlah, Jurnal Pendidikan dan Studi Islam 5, no. 1 (2019): 1-18. 
- - . "Urgensi Inovasi Pembelajaran Islam Dalam PAI." al-Afkar, Journal for Islamic Studies 2, no. 1 (2019): 64-86.

Rosyad, Ali Miftakhu, and Muhammad Anas Maarif. "PARADIGMA PENDIDIKAN DEMOKRASI DAN PENDIDIKAN ISLAM DALAM MENGHADAPI TANTANGAN GLOBALISASI DI INDONESIA.” Nazhruna: Jurnal Pendidikan Islam 3, no. 1 (2020): 75-99.

Sadir, Darwis. "Piagam Madinah (Al-Qanun)." Jurnal Pemikiran dan Pembaharuan Hukum Islam 5, no. 1 (2013): 250-257.

Shihab, Quraish. Tafsir Al-Misbah, Pesan, Kesan Dan Keserasian Al-Qur'an. Jakarta: Lentera Hati, 2002.

TERRENCE E. DEAL., KENT D. PETTERSON. "SHAPING SCHOOL CULTURE" (n.d.).

Wibowo, Adi. "Tinjauan Hukum Islam Terhadap Praktik Pinjammeminjam Uang Di Desa Nglorog Kec. Sragen Kab. Sragen.” Skripsi--UIN Sunan Kalijaga, Yogyakarta (2013).

Nur ad-diin bin mukhtar al- khodimi, Ilmul maqoshid asy-syar'iyyah, maktabah al abyikan. Terbitan pertama, 2001.

DR. Muhammad sodqiy al ghaziy, Al wajiz fi idohi qowaidil fiqhil kuliyyah, mu'assasah ar-risalah beirut libanon, 1996.

As- suyuthi , Al-asybahu wan-nadzoir, dar- alkutub al ilmiyah, cetakan pertama, 1990.

Az-zarkasyi, almantsur fil qowaidil fiqhiyah,wizarotul awqof al-kuwaitiyah, cetakan ke dua, 1985.

Iz ad-diin bin abdis salam, al fawaid fi ikhtishoril maqoshid, dar- alfikri, damaskus, cetakan pertama $1416 \mathrm{~h}$.

Muhammad tohir hakim, ri'ayatul maslahah wal hikmatu min tasyri'i nabiyyirrohmah, al jami'ah al islamiyah, madina, 2002.

Ali muhammad jarisyah, al maslahah almursalah, muhawalatan libastiha wa nadzrotin fiha, jami'ah islamiyah, madina al munawwarah, 1997.

Muhammad tohir hakim, ri'ayatul maslahah wal hikmatu min tasyri'i nabiyyirrohmah, jamiah islamiyah, madinah al munawwarah, 2002.

Muhammad hasan abdul ghoffar. Taysiru ushulil fiqhi lilmubtadi'in, mawqi' yabkah islamiyah.

Iz- ad-din bin abdis- salam, Qowaidul ahkam fi masholihil anam, maktabah kuliyyah al- ashariyah, kairo, 1991.

Az-zarkasyiy, tasyniful masami' bisyarhi jam'il jawami', maktabah qurtubiyah, cetakan pertama, 1998.

Az-zarkasyiy, al-bahrul muhith fi ushulil fiqh, darul kutubiy, cetakan pertama, 1994.

Walid bin rosyid sa'idan, talqihul afhamil aliyah bisyarhil qowa'idil fiqhiyah

Asy-syatibiy, al muwafaqot, dar- ibnu affan, cetakan pertama, 1997.

Ahmad bin muhammad makkiy, ghomzu 'uyunil basho'ir fi syarhil asybah wannadzo'ir, darul kutub al-ilmiyah, cetakan pertama, 1985.

Abu ja'far ath-thabari, tafsir jami'ul bayan, mu'asssasah ar- risalah, cetakan pertama, 2000 


\section{Fajri Syahroni Siregar}

Investasi Dana Haji untuk Pembangunan......

Al-jurjani. Durjud duror fi tafsiril ayi was-suwar, mu'assasah ar-risalah, majallat alhikmah britania, 2008.

Asy-syairozi. Al-muhadzdzab fi fiqhil imam asy-syafi'i, dar al-kutub al- ilmiah.

Al-mawardi, al iqna' fil fiqhi asy-syafi'i.

Al-umroni, al-bayan fi madzhabil imam asy-syafi'i, dar al-minhaj, cetakan pertama, 2000.

An-nawawi, al-majmu' syarhul muhadzdzab, dar al-fikri.

An-nawawi, roudhotut-tholibin wa 'umdatul muftin, al maktab al- islami, cetakan pertama, 1991.

Ikatan Akuntan Indonesia.. Pernyataan Standar Akuntansi Keuangan 16. Jakarta: Salemba Empat. 2009

https://informasiana.com/pengertian-infrastruktur 